\title{
Selecting Sustainable ICT Solutions for Pro-poor Intervention
}

\author{
Kim I. Mallalieu and Sean Rocke ${ }^{1}$ \\ DEPARTMENT OF ELECTRICAL AND COMPUTER ENGINEERING \\ The University of the West Indies, St. Augustine, Trinidad and Tobago
}

\begin{abstract}
This chapter describes a Percolator model as a framework within which ICT solutions may be contemplated for communities under threat of digital exclusion. The model partitions the problem into manageable domains, within which realistic and appropriate ICT solutions may be progressively distilled. It gives an account of the generic attributes of information and communications and the manner in which these attributes map onto technical parameters of ICT. The model places a great deal of emphasis on contextualization, drawing on the Sustainable Livelihood Approach for intervention in economically poor communities. Its domains variously take account of the national or provincial developmental objectives in particular politico-cultural contexts as well as the social character of communities and their physical nature. Ultimately, contextualized technical parameters are used as the basis on which solutions are selected from among the available range of information and communications technologies. The general framework of the Percolator model is not limited to ICT. It may be applied to intervention based on a variety of technologies.
\end{abstract}

${ }^{1}$ The authors acknowledge, with gratitude, the contribution of Akash Pooransingh in the acquisition of supporting resources for this work. 
ICTs have been inextricably linked to social development (UNDP, 1996; UNDP, 1999; G-8, 2000; DFID, 2002; World Bank, 1999; Cecchini \& Shah, 2002). Yet there are poles of opinion regarding the application of these technologies in communities for which they find no natural or ready home. Many authors have analyzed the fundamental as well as the practical sources of failure in these communities (Avgerou, 2000) while many have reported on its tremendous successes. Indeed, the deployment of ICT in digitally impoverished communities by digitally privileged ones is fraught with pitfalls, most particularly when they are contemplated as an a priori solution to general or ill defined problems, with little regard for communities' cultural, social and physical nature.

History has shown that ICT can enable the realization of social developmental objectives to the extent that they can enable appropriate and long-lasting lifestyle changes. It is imperative, therefore, that ICT-based intervention takes account, not only of the technologies themselves, but also of the ultimate developmental objectives and, very importantly, of the many factors which impact on sustainability.

We posit that there are fundamental principles which underlie the success of ICT intervention by external agents, namely that:

1. Such intervention must be ultimately driven by general developmental objectives as articulated by national or provincial policy.

2. These ultimate developmental objectives may only be achieved through the parallel engagement of many sectors.

3. ICT is one such sector.

We further posit that successful ICT-based intervention is:

- Driven from the bottom as well as from the top

- $\quad$ Structured according to independent but interacting domains

Based on these fundamental principles, the authors have developed a framework for the contemplation of ICT solutions for digitally poor communities which, as Barrantes' chapter in this book demonstrates, are not restricted to communities that are economically poor.

Recognizing the essential multi-disciplinary, multi-sectoral nature of development and the vast and multi-faceted nature of the proposition of intervention, the framework is partitioned into component domains. Application of the framework draws upon a number of existing analytical as well as operational tools. 


\section{The Percolator Model}

The authors define a "Percolator model" as a framework to guide the selection of technological intervention solutions for communities of interest. This Percolator model is illustrated for ICT-based intervention in Figure 1. It comprises three domains: the broad contextual or "Base" Domain, the User Domain and the Technology Domain. The Base Domain loosely defines the scope of livelihoods which are compatible with national or provincial developmental objectives and are at the same time realistic in a particular political and cultural setting. The User Domain defines technical requirements that derive from the attributes ascribed to information and communications in the context of traditions of abilities and interaction as well as from sectoral objectives, where such exist. The Technology Domain defines the set of ICT solutions, from amongst the available set of information and communications technologies, which are well suited to the physical context of particular communities and which are constrained by the technical requirements that have percolated up the two underlying domains.

Figure 1: Percolator Model for Contemplating ICT Intervention Solutions

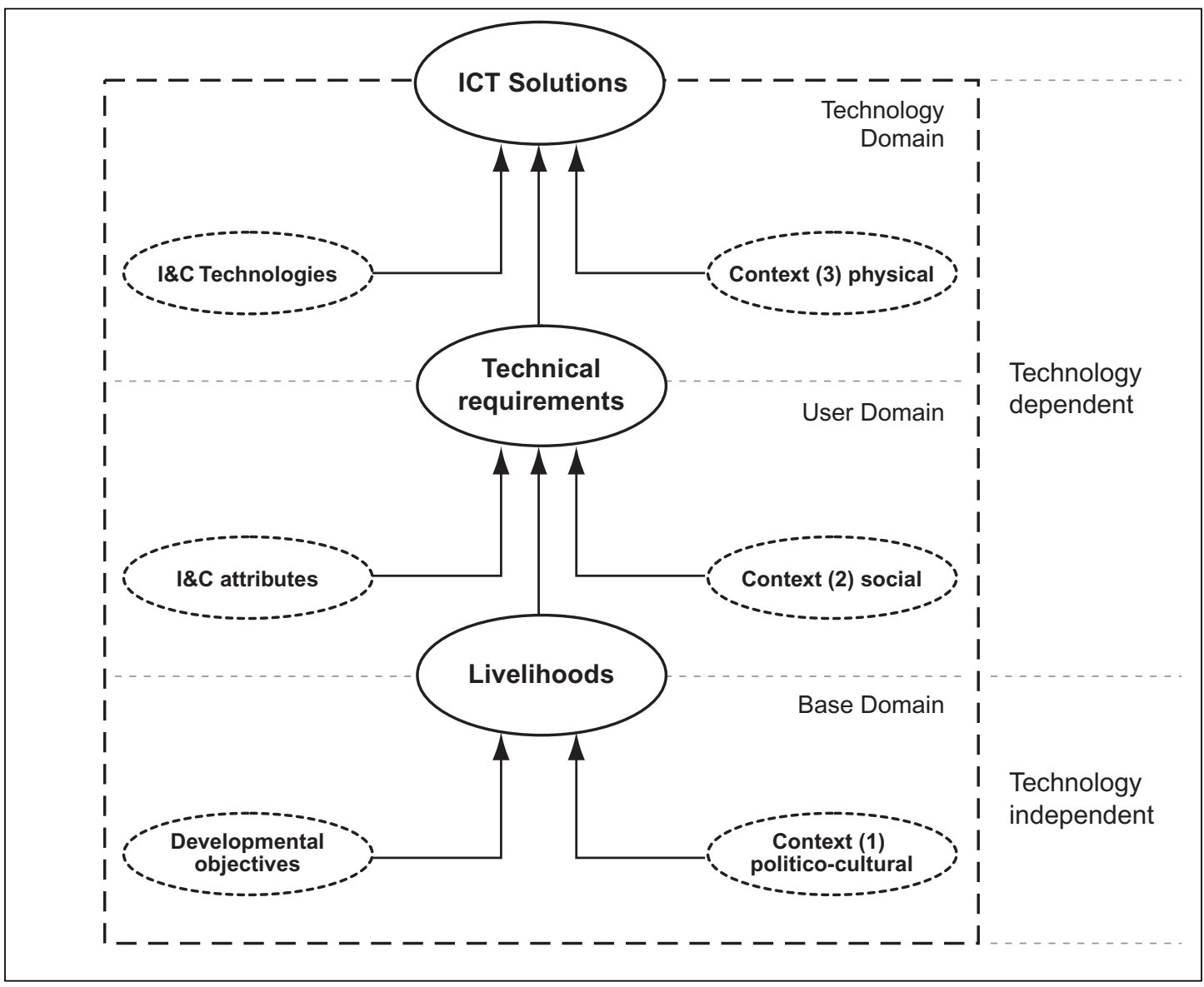


Each of the domains in the Percolator model is situated in the context of a predominant discipline: politico-cultural, social and physical. The domains interact through well defined interfaces across which solution baskets are passed. These baskets (livelihoods, technical requirements and ultimately, ICT solutions) represent distillations of requirements and considerations, drawn from the backdrop of various predominant disciplines. The baskets progressively constrain the ultimate solution as their refinements percolate up the model. The philosophical underpinnings of the model are reflected in this progressive "percolation" of solution features which ultimately constrain the choice of technological solutions.

While the User and Technology domains of the Percolator model are technology dependent, the Base Domain is technology independent. The livelihoods that derive from this domain form the basis of many solution "trees" which may be conceived using fundamentally different technologies.

\subsection{AN EXAMPLE ICT SOLUTION TREE}

As an example, an ICT solution tree may be built on a Base domain which favours trade as a key dimension of community livelihood. In this domain, the selection of trade is made on the basis of the political and cultural context of the community and on the basis that trade is an effective avenue to realize economic development as one important national objective.

In the User domain, an ICT solution tree defines the attributes ascribed to information and communications, for example quantity and quality of information and its flow characteristics. Information and communications attributes appropriate to the community are selected from among these on the basis of appropriate livelihoods, as defined in the Base domain, as well as on the basis of the social context of the community. For example the type of trade envisioned may require the communication of the equivalent of 6,000 words of locally-generated information between one central location and fifty homes twice each day. The social context may constrain the technical requirements of information and communications technologies to audio or visual formats rather than text-based formats, as would be the case for communities in which the levels of basic literacy are very low. Another of the many aspects of the social context is the profile of the community's existing communications uptake. For example, if the vast majority of households enjoy television, a technical requirement may be that the user interface is a television.

In the Technology domain, a variety of information and communications technologies are defined. Those whose user interface is a television include various technologies which use terrestrial microwave transmission as well as cable, LMDS and different satellite technologies. Many factors derived from the community's 
physical context strongly influence the selection from among these technologies. These include the penetration rates of televisions in homes; the installed base, and state of repair, of existing television distribution infrastructure; the terrain; the geographical extent of the community and the distribution of households within the community. Taking account of these physical considerations in the community of interest, as well as of the technical requirements articulated by the User domain, the ultimate ICT solution for this community may be Low Power Television (LPTV).

\section{Contextualization in the Percolator Model}

The Percolator model recognizes the tremendous significance of context in the ultimate selection of technologies to facilitate development. This is especially so for technologies which serve an indirect purpose, as is the case for ICT in pro-poor intervention. For these communities, the model borrows heavily from the UNDP Sustainable Livelihood Approach, SLA (Singh \& Wanmali, 1998; Wanmali, 1998; Ashley \& Carney; 1999) and DFID's Sustainable Livelihoods (SL), which are driven by an assessment of community strengths and assets rather than by an assessment of (perceived) needs. ${ }^{2}$

The many contextual parameters taken into account in SL include "the priorities that people identify; the different strategies they adopt in pursuit of their priorities; the institutions, policies and organizations that determine their access to assets/opportunities and the returns they can achieve; their access to social, human, physical, financial and natural capital, and their ability to put these to productive use and the context in which they live, including external trends (economic, technological, demographic, etc.), shocks (natural or man-made), and seasonality" (Ashley \& Carney, 1999).

These context parameters, and many more, are fundamental to the proposition that ICT can effectively impact on economic poverty alleviation. Economic and enterprise parameters are less important to the alleviation of digital poverty but social parameters are equally important.

The Percolator model accounts for context parameters according to their domain/s of influence (Base, User and Technology) and to the extent to which the impact they exert is of primary or secondary importance. Parameters that exert stronger ("primary") influence are weighted more heavily than those that exert less ("secondary") influence.

\footnotetext{
${ }^{2}$ Guidance Sheets available at http://www.livelihoods.org/info/info_guidancesheets.html\#7.
} 


\section{The Base Domain}

Digitally impoverished communities differ in very many ways including their physical extent, level of urbanization, culture, geography and demographics. SLA advances a comprehensive approach to determining sustainable livelihoods by taking account of the macro-, micro and sectoral policies that impact on livelihood and the use of individual and collective assets as well as community strengths, constraints, institutions and priorities to envision new and nominally-disruptive livelihoods. In the Base Domain of the Percolator model, features of appropriate livelihoods are developed through standard technology-independent SLA analysis. Case studies, included in the DFID Guidance Sheets and elsewhere (e.g. Singh \& Wanmali, 1998; Ashley \& Carney, 1999), describe how the analysis can be performed to establish general features of the many dimensions of sustainable livelihoods in a variety of different communities.

SLA provides the overarching framework for the Percolator model. The model adds fresh insights into the process of selecting information and communications technologies for sustainable livelihoods and therefore focuses much of its attention on the User and Technology Domains.

\section{The User Domain}

Objectives for ICT-based intervention may be categorized as secondary or as primary. Secondary objectives comprise all developmental targets that may be achieved indirectly through the application of ICT, for example those relating to the Millennium Development Goals. These include health, education, environmental sustainability and enterprise. Secondary objectives are technology independent and are implicitly accounted for in the livelihoods that percolate up to the User domain from the Base domain.

Primary objectives are specified in terms of sectoral metrics which, for ICT-based pro-poor intervention relate directly to digital poverty. Barrantes' chapter in this book discusses the notion of digital poverty and analyses the demand side of ICT in digitally impoverished communities. This analysis, together with other realities such as the profile of basic literacy within a community, constitutes the social context for ICT-based intervention and is accounted for in the User Domain of the Percolator model.

\subsection{ATTRIBUTES OF INFORMATION AND COMMUNICATIONS}

The attributes of information and communications constitute the other major category of considerations in the User Domain of an ICT solution tree in the Percolator 
model. These generic attributes are independent of the specific technologies used to deliver information and communications services. The decoupling of information and communications attributes from information and communications technologies is key to the Percolator model as it enables the ultimate selection of technologies on the basis of the features of information (useful to particular communities) and on the basis of suitable ways in which community members communicate this information.

The basic attributes ascribed to generic information are:

1. Its intrinsic format (e.g., audio, image, numeric, etc.)

2. The quantity of data required to represent it digitally.

As all forms of intrinsic information may be represented and communicated digitally, communications attributes have less to do with the intrinsic form of the information conveyed and more to do with its data equivalence and the needs of communicating parties. For example if two community members wish to communicate with each other through conversational voice while two others wish to communicate through voice messaging, the nature of the intrinsic information, audio, is unchanged while the communications attributes (synchronous in the first case and asynchronous in the second) are quite different.

As another example, members of a community may lack basic literacy and therefore not be able to interact through text-based information. For such a community, information may only be effectively communicated through video or audio means. In this case, the social context constrains the communications attribute to a particular medium (video or audio), independent of the native format of the information to be communicated.

Accordingly, Table 1 documents the range of attributes that may be ascribed to the communication of information and inherently incorporates the notion of the quantity of (digital) information to be communicated.

The table categorizes communications attributes according to whether or not the medium is constrained by social factors as well as to its rate, its flow, its symmetry, its topology and the extent to which mobility and ubiquity are required. The table includes attributes that relate to key social parameters of particular communities, for example where access points are located and users' requirements for familiarity with communications appliances as well as the value they place on the appliances' ease of use and flexibility. 
Table 1: Information and Communications Attributes with Qualitative Reference Points

\begin{tabular}{|c|c|c|c|}
\hline \multirow{2}{*}{$\begin{array}{l}\text { Communications } \\
\text { Attributes }\end{array}$} & \multicolumn{3}{|c|}{ Reference Points } \\
\hline & Low & Mid-range & High \\
\hline \multicolumn{4}{|l|}{ Basic attributes } \\
\hline $\begin{array}{l}\text { i) Medium, if } \\
\text { constrained }\end{array}$ & $\begin{array}{l}\text { Constrained to audio } \\
\text { (or unconstrained) }\end{array}$ & $\begin{array}{l}\text { Text-based (or } \\
\text { unconstrained) }\end{array}$ & $\begin{array}{l}\text { Constrained to video } \\
\text { (or unconstrained) }\end{array}$ \\
\hline ii) Rate & Low & Moderate & High \\
\hline iii) Flow & Interactive & Streaming & Conversational / real time \\
\hline iv) Mobility & None (fixed) & Low mobility & High mobility \\
\hline v) Symmetry & One way only & One way at a time & 2-way simultaneously \\
\hline vi) Topology & $\begin{array}{l}\text { Two particular } \\
\text { communicators }\end{array}$ & $\begin{array}{l}\text { One to many particular } \\
\text { communicators }\end{array}$ & $\begin{array}{l}\text { Arbitrary one to one } \\
\text { communicators }\end{array}$ \\
\hline vii) Ubiquity & $\begin{array}{l}\text { Access only to } \\
\text { local community }\end{array}$ & $\begin{array}{l}\text { Access to local } \\
\text { community and to other } \\
\text { particular communities }\end{array}$ & $\begin{array}{c}\text { Global access, access } \\
\text { to the Internet and / or } \\
\text { to the PSTN }\end{array}$ \\
\hline $\begin{array}{l}\text { viii) Location of } \\
\text { access points }\end{array}$ & Single centre & Multiple centres & Anywhere \\
\hline \multicolumn{4}{|c|}{ Attributes of Appliance } \\
\hline i) Familiarity & Very familiar & Moderately familiar & Not familiar at all \\
\hline ii) Usability & Very easy to use & Manageable & Complicated \\
\hline iii) Flexibility & $\begin{array}{l}\text { Inflexible: supports } \\
\text { single application }\end{array}$ & $\begin{array}{l}\text { Somewhat flexible: } \\
\text { supports limited } \\
\text { range of applications }\end{array}$ & $\begin{array}{l}\text { Very flexible: } \\
\text { supports rich variety } \\
\text { of applications }\end{array}$ \\
\hline
\end{tabular}

Information and communications attributes are important as the social basis for selecting technological solutions which are appropriate to, and adopted by, communities of interest. Their correspondence with physical, human, social and cultural factors is therefore very important as the latter figure strongly in the adoption, application, and use of new technologies in general and ICT in particular (e.g. Tse et al., 2004).

The attributes of Table 1 bare natural linkages to their application in a social setting. For example they describe the quantity and flow of information to be communicated using ICT, the relationships between communicating entities, the manner in which they interact, the extent to which they are on the move while they communicate and where they communicate from. The attributes also describe the ultimate (global) geographic reach of communications from the community and capture considerations relating to user needs with respect to the devices they use to communicate.

Table 2 provides a matrix of technical parameters that correspond to the attributes of Table 1. These parameters include format, data rate, delay, delay variation, frame error rate, transmission media, MAC protocol, transmission symmetry, logical and physical topology, internetworking, profile of uptake locally, regionally and globally, as well as the level of technological maturity and the simplicity and range 
of capabilities of the end user appliance.

Low, mid-range and high values for each parameter are provided in Table 2. Parameter values do not correlate down columns as the entries are independent of each other. In general, particular communications profiles are therefore described by some mix of low-range, mid-range and high-range parameters.

Table 2: Technical Parameters Corresponding to Communications Attributes

\begin{tabular}{|c|c|c|c|c|}
\hline \multirow{2}{*}{$\begin{array}{l}\text { Communications } \\
\text { Attribute }\end{array}$} & \multirow{2}{*}{$\begin{array}{c}\text { Corresponding } \\
\text { Technical Parameter }\end{array}$} & \multicolumn{3}{|c|}{ Reference Points for Technical Parameter } \\
\hline & & Low & Mid-range & High \\
\hline \multicolumn{5}{|l|}{ Basic attributes } \\
\hline $\begin{array}{l}\text { i) Medium, if } \\
\text { constrained }\end{array}$ & Format & Audio & Text & Video \\
\hline ii) Rate & Data rate & $4-64$ kbps & $\approx 384 \mathrm{kbps}$ & $\geq 10 \mathrm{Mbps}$ \\
\hline \multirow[t]{3}{*}{ iii) Flow } & Delay & $>10 \mathrm{sec}$ & $>150 \mathrm{~ms} ;<10 \mathrm{sec}$ & $<150 \mathrm{~ms}$ \\
\hline & Delay variation & $\mathrm{N} / \mathrm{A}$ & $\mathrm{N} / \mathrm{A}$ & $<1 \mathrm{~ms}$ \\
\hline & Frame Error Rate & $<3 \%$ & $<1 \%$ & $0 \%$ \\
\hline \multirow[t]{2}{*}{ iv) Mobility } & Transmission Media & Wired or wireless & Wireless & Wireless \\
\hline & MAC Protocol & $\mathrm{N} / \mathrm{A}$ & $\begin{array}{c}\text { Mobility } \\
\text { management }\end{array}$ & $\begin{array}{c}\text { Mobility } \\
\text { management }\end{array}$ \\
\hline v) Symmetry & $\begin{array}{l}\text { Transmission } \\
\text { symmetry }\end{array}$ & Simplex & Half duplex & Full duplex \\
\hline vi) Topology & Logical topology & Point to point link & Broadcast network & Peer to peer network \\
\hline \multirow[t]{2}{*}{ vii) Ubiquity } & Internetworking & $\begin{array}{l}\text { Stand alone local } \\
\text { network }\end{array}$ & $\begin{array}{c}\text { Local net linked to } \\
\text { specific other } \\
\text { community nets }\end{array}$ & $\begin{array}{l}\text { Local network with } \\
\text { backhaul to the } \\
\text { Internet } \\
\text { and/or to PSTN }\end{array}$ \\
\hline & $\begin{array}{l}\text { Profile of local, } \\
\text { regional and } \\
\text { global uptake }\end{array}$ & $\begin{array}{l}\text { One of: local, } \\
\text { regional, global } \\
\text { or minimal } \\
\text { installed base }\end{array}$ & $\begin{array}{l}\text { Two of: local, } \\
\text { regional, global or } \\
\text { only modest } \\
\text { installed base }\end{array}$ & $\begin{array}{l}\text { Widespread } \\
\text { local, regional } \\
\text { and global } \\
\text { deployment }\end{array}$ \\
\hline $\begin{array}{l}\text { viii) Location of } \\
\text { access points }\end{array}$ & Physical topology & Single link & Thin network & Dense network \\
\hline \multicolumn{5}{|c|}{ Attributes of Appliance } \\
\hline i) Familiarity & i) Maturity & $\begin{array}{c}\text { Mature technology } \\
\text { familiar end user } \\
\text { appliance and } \\
\text { operation }\end{array}$ & $\begin{array}{c}\text { Well established } \\
\text { technology: familiar } \\
\text { end user appliance } \\
\text { but new operation } \\
\text { or vice versa }\end{array}$ & $\begin{array}{l}\text { New technology: } \\
\text { unfamiliar end } \\
\text { user appliance } \\
\text { and operation }\end{array}$ \\
\hline ii) Usability & ii) Simplicity & $\begin{array}{l:}\text { No installation or } \\
\text { configuration } \\
\text { required of user. } \\
\text { Operation simple }\end{array}$ & $\begin{array}{c}\text { Some installation } \\
\text { and configuration } \\
\text { required of user. } \\
\text { Operation } \\
\text { somewhat simple }\end{array}$ & $\begin{array}{l}\text { Complicated } \\
\text { installation, } \\
\text { configuration \& } \\
\text { operation }\end{array}$ \\
\hline iii) Flexibility & iii) Range & $\begin{array}{l}\text { Supports only } \\
\text { basic } \\
\text { communications }\end{array}$ & $\begin{array}{c}\text { Supports } \\
\text { entertainment and } \\
\text { access to services }\end{array}$ & $\begin{array}{l}\text { Supports a wide } \\
\text { range of } \\
\text { applications } \\
\text { including revenue } \\
\text { generating ones }\end{array}$ \\
\hline
\end{tabular}


The table only represents the technical parameters that correspond to communications attributes which are of direct significance to users. It does not represent the many derivative technical parameters such as channel bandwidth whose requirements are derived from a combination of the required data rate, coding, modulation scheme and Bit Error Rate.

Tables 3 and 4 provide an example which illustrates the manner in which the attributes of information and communications appropriate to a particular social context maps onto technical parameters.

In the example of Tables 3 and 4, low data rate, one way communications conveying streaming (voice) information between arbitrary communicators anywhere in a local community using a familiar user interface without support for mobility is satisfied by the provision of simplex communications over a wired or wireless peer to peer network with the following technical requirements: a data rate of $4 \mathrm{kbps}$, a delay variation of less than $1 \mathrm{~ms}$, a frame error rate of less than $3 \%$ and little constraint on absolute delay.

The generic technical requirements that emerge from the User domain 'percolate up' to the Technology domain where specific ICT solutions are derived, taking addi-

Table 3: Example Profile of ICT Attributes

\begin{tabular}{|c|c|c|c|}
\hline \multirow{2}{*}{$\begin{array}{l}\text { Communications } \\
\text { Attributes }\end{array}$} & \multicolumn{3}{|c|}{ Reference Points } \\
\hline & Low & Mid-range & High \\
\hline \multicolumn{4}{|l|}{ Basic attributes } \\
\hline $\begin{array}{l}\text { i) Medium, if } \\
\text { constrained }\end{array}$ & $\frac{\text { Constrained to audio }}{\text { (or unconstrained) }}$ & $\begin{array}{l}\text { Text-based (or } \\
\text { unconstrained) }\end{array}$ & $\begin{array}{l}\text { Constrained to video } \\
\text { (or unconstrained) }\end{array}$ \\
\hline ii) Rate & Low & Moderate & High \\
\hline iii) Flow & Interactive & Streaming & Conversational / real time \\
\hline iv) Mobility & None (fixed) & Low mobility & High mobility \\
\hline v) Symmetry & One way only & One way at a time & 2-way simultaneously \\
\hline vi) Topology & $\begin{array}{l}\text { Two particular } \\
\text { communicators }\end{array}$ & $\begin{array}{l}\text { One to many particular } \\
\text { communicators }\end{array}$ & $\frac{\text { Arbitrary one to one }}{\text { communicators }}$ \\
\hline vii) Ubiquity & $\begin{array}{l}\text { Access only to } \\
\text { local community }\end{array}$ & $\begin{array}{l}\text { Access to local } \\
\text { community and to other } \\
\text { particular communities }\end{array}$ & $\begin{array}{c}\text { Global access, access } \\
\text { to the Internet and / or } \\
\text { to the PSTN }\end{array}$ \\
\hline viii) Access points & Single centre & Multiple centres & Anywhere \\
\hline \multicolumn{4}{|c|}{ Attributes of Appliance } \\
\hline i) Familiarity & Very familiar & Moderately familiar & Not familiar at all \\
\hline ii) Usability & Very easy to use & Manageable & Complicated \\
\hline iii) Flexibility & $\begin{array}{l}\text { Inflexible: supports } \\
\text { single application }\end{array}$ & $\begin{array}{l}\text { Somewhat flexible: } \\
\text { supports limited } \\
\text { range of applications }\end{array}$ & $\begin{array}{l}\text { Very flexible: } \\
\text { supports rich variety } \\
\text { of applications }\end{array}$ \\
\hline
\end{tabular}


tional account of physical contextualization and the available range of ICT. In the example illustrated by Tables 3 and 4, voice messaging over the PSTN would be strongly suggested if the community enjoys a comprehensive PSTN installed base.

Table 4: Technical Parameters (Linked to Corresponding Service Attributes) with Reference Points for Technical Requirements

\begin{tabular}{|c|c|c|c|c|}
\hline \multirow{2}{*}{$\begin{array}{l}\text { Communications } \\
\text { Attribute }\end{array}$} & \multirow{2}{*}{$\begin{array}{c}\text { Corresponding } \\
\text { Technical Parameter }\end{array}$} & \multicolumn{3}{|c|}{ Reference Points for Technical Parameter } \\
\hline & & Low & Mid-range & High \\
\hline \multicolumn{5}{|l|}{ Basic attributes } \\
\hline $\begin{array}{l}\text { i) Medium, if } \\
\text { constrained }\end{array}$ & Format & Audio & Text & Video \\
\hline ii) Rate & Data rate & $4-64$ kbps & $\approx 384 \mathrm{kbps}$ & $\geq 10 \mathrm{Mbps}$ \\
\hline \multirow[t]{3}{*}{ iii) Flow } & Delay & $\geq 10 \mathrm{sec}$ & $>150 \mathrm{~ms} ;<10 \mathrm{sec}$ & $<150 \mathrm{~ms}$ \\
\hline & Delay variation & N/A & $\mathrm{N} / \mathrm{A}$ & $<1 \mathrm{~ms}$ \\
\hline & Frame Error Rate & $\leq 3 \%$ & $\leq 1 \%$ & $0 \%$ \\
\hline \multirow[t]{2}{*}{ iv) Mobility } & Transmission Media & Wired or wireless & Wireless & Wireless \\
\hline & MAC Protocol & $\underline{\text { N/A }}$ & $\begin{array}{c}\text { Mobility } \\
\text { management }\end{array}$ & $\begin{array}{c}\text { Mobility } \\
\text { management }\end{array}$ \\
\hline v) Symmetry & $\begin{array}{l}\text { Transmission } \\
\text { symmetry }\end{array}$ & Simplex & Half duplex & Full duplex \\
\hline vi) Topology & Logical topology & Point to point link & $\begin{array}{l}\text { Broadcast } \\
\text { network }\end{array}$ & $\frac{\text { Peer to peer }}{\text { network }}$ \\
\hline \multirow[t]{2}{*}{ vii) Ubiquity } & Internetworking & $\begin{array}{l}\text { Stand alone } \\
\text { local network }\end{array}$ & $\begin{array}{l}\text { Local net linked to } \\
\text { specific other } \\
\text { community nets }\end{array}$ & $\begin{array}{l}\text { Local network } \\
\text { with backhaul to } \\
\text { the Internet } \\
\text { and/or to PSTN }\end{array}$ \\
\hline & $\begin{array}{l}\text { Profile of local, } \\
\text { regional and } \\
\text { global uptake }\end{array}$ & $\begin{array}{l}\text { One of: local, } \\
\text { regional, global } \\
\text { or minimal } \\
\text { installed base }\end{array}$ & $\begin{array}{l}\text { Two of: local, } \\
\text { regional, global or } \\
\text { only modest } \\
\text { installed base }\end{array}$ & $\begin{array}{l}\text { Widespread } \\
\text { local, regional } \\
\text { and global } \\
\text { deployment }\end{array}$ \\
\hline $\begin{array}{l}\text { viii) Location of } \\
\text { access points }\end{array}$ & Physical topology & Single link & Thin network & Dense network \\
\hline \multicolumn{5}{|c|}{ Attributes of User Interface } \\
\hline i) Familiarity & i) Maturity & $\begin{array}{c}\text { Mature technology } \\
\frac{\text { familiar end user }}{\text { appliance and }} \\
\text { operation }\end{array}$ & $\begin{array}{l}\text { Well established } \\
\text { technology: familiar } \\
\text { end user appliance } \\
\text { but new operation } \\
\text { or vice versa }\end{array}$ & $\begin{array}{l}\text { New technology: } \\
\text { unfamiliar end } \\
\text { user appliance } \\
\text { and operation }\end{array}$ \\
\hline ii) Usability & ii) Simplicity & $\begin{array}{l}\text { No installation or } \\
\text { configuration } \\
\text { required of user. } \\
\text { Operation simple }\end{array}$ & $\begin{array}{l}\text { Some installation } \\
\text { and configuration } \\
\text { required of user } \\
\text { Operation } \\
\text { somewhat simple }\end{array}$ & $\begin{array}{l}\text { Complicated } \\
\text { installation, } \\
\text { configuration \& } \\
\text { operation }\end{array}$ \\
\hline iii) Flexibility & iii) Range & $\begin{array}{l}\text { Supports only } \\
\text { basic } \\
\text { communications }\end{array}$ & $\begin{array}{l}\text { Supports } \\
\text { entertainment and } \\
\text { access to services }\end{array}$ & $\begin{array}{l}\text { Supports a wide } \\
\text { range of } \\
\text { applications } \\
\text { including revenue } \\
\text { generating ones }\end{array}$ \\
\hline
\end{tabular}




\section{The Technology Domain}

The Technology Domain defines the range of available technologies, their corresponding technical characteristics and the manner in which physical considerations constrain their use. These technologies are evaluated against the technical requirements established by the User Domain in order to propose contextually appropriate information and communications technologies.

Key categories of ICT of relevance to pro-poor intervention are access technologies, access device technologies and application technologies. The first play a central role in the penetration of ICT into digitally poor communities while the second and third figure strongly in the level of uptake by community members.

\subsection{ACCESS TECHNOLOGIES}

Access technologies are those that enable communication between end users and core networks. They are the conduit, as it were, for the delivery of communications services from service providers directly to end users. Technologies traditionally used for this purpose include telephony, television and radio, the latter including amateur and other forms of push to talk technologies. Not withstanding the fact that data communications has proliferated over the past few decades, these traditional access technologies and their modern variants, such as digital TV, are important propositions for intervention.

At the other end of the spectrum lie fiber optic access technologies. Their high bandwidth, combined with superlative quality, make these the technologies of choice, where available, for fixed users with flexible budgets and sophisticated application requirements. The substantial infrastructural and deployment costs, low architectural reconfigurability and flexibility as well as limited deployment, make them unattractive for traditionally poor communities in developing countries.

The many wired broadband access technologies which utilize traditional infrastructure at relatively low marginal cost offer significant potential for communities in which the infrastructure exists. Such technologies include Broadband over PowerLine (BPL), which uses the ubiquitous installed base of power distribution companies, as well as Cable access and XDSL which leverage existing Cable TV and POTS infrastructure respectively.

Wireless access technologies have attracted a great deal of attention for unconnected communities (see for example Jhunjhunwala \& Orne, 2003). The most compelling advantages of these technologies are the ease, speed and low cost of deployment which can enable rapid and widespread ICT diffusion. Within the smorgasbord of wireless access possibilities, cellular networks offer mobility as well as par- 
ticularly wide coverage. Like cellular wireless technologies, satellite-based access technologies offer wide coverage but variously with and without mobility. Many offer the additional benefit of swift installation and, for this reason, are particularly useful in disaster recovery and other applications which require rapid deployment of temporary communications services. While cellular and satellite technologies generally feature wide coverage, wireless LAN (WLAN) technologies such as WiFi, WiMAX and Mobile-Fi deliver particularly high data rates at limited mobility and some broadband wireless access technologies, such as MMDS and LMDS, represent fixed wireless solutions.

Much has been documented on the technical features of various access technologies. Comparisons between access technologies are also widely available in the literature, for example WiFi has been compared to 3G cellular (Lehr \& McKnight, 2003), to Bluetooth (Ferro \& Potorti, 2005), to WiMax (Otero, 2004) and to other 3G alternatives (Alvén et al., 2001).

\subsection{ACCESS DEVICE TECHNOLOGIES}

Communications appliances, often referred to as "access devices", represent the interface through which users access information and communications services. They are of considerable significance within the Percolator Model as they are associated with various context parameters such as affordability, availability, simplicity, interactivity, mobility, ubiquity, accessibility, computational power, power requirements, portability, user friendliness and environmental operating features. These context parameters are accounted for partly in the User domain and partly in the Technology domain.

Devices traditionally used to access communications services include the land line telephone, the television and various forms of radio. Many digitally poor communities have long traditions of radio and television access. Especially for communities in which basic literacy rates are very low, these appliances figure strongly in the selection of access device technology and correspondingly to access technologies themselves. A rich array of television and broadcast radio technologies exists, many of which feature transition paths to digital literacy. Set top boxes, for example, may be used with traditional television appliances and keyboards to access the Internet.

Other access devices include mobile phones, desktop PCs, handhelds and even the Simple Inexpensive Multilingual People's Computer, Simputer, the VolksComputer (Riti, 2001; Vaughan, 2005) and the VillagePDA (Wattegama, 2004). Many of these cater for the special needs of various communities by, for example, making use of touch screens for users who lack basic literacy skills and by featuring interfaces in local languages. 


\subsection{APPLICATION TECHNOLOGIES}

Application technologies refer to the end user capabilities possible through information and communications technologies. These capabilities, "applications", refer to software programs which run on access devices in order to provide value added capabilities on top of basic communications services or to the capabilities enabled directly through basic communications services. Examples of the former are email clients and Web browsers which run on access devices and through which email and Web browsing services are possible, respectively. An example of the latter is television, which is accessible directly from the access device.

The proposition of ICT-based intervention is intimately tied to end user applications. This association is built into each layer in the Percolator model, with the strongest influence accounted for in the Base domain which defines the general scope of activities that ICT applications facilitate, for example farming, trade, industry, health, education, commerce etc. Applications consistent with this general scope and satisfying the technical requirements articulated in the User domain, are selected in the Technology domain taking additional account of many aspects of the physical context of the community.

\subsection{PHYSICAL CONTEXT}

The Base and User Domains of the Percolator Model take into consideration various human and social context parameters that collectively constrain the choice of ICT for sustainable development in communities under threat of digital exclusion. The Technology Domain refines the range of suitable ICT, not only on the basis of the range of available technologies and their technical requirements for particular communities, as percolated up from the Base and User domains, but also on the basis of the physical context which characterizes particular application environments.

The physical parameters that impact on the choice of ICT for pro-poor intervention are widely varied and include environmental and topographical profiles of communities, many dimensions of the physical wherewithal of community members as well as the physical availability of human resource, infrastructural and ancillary support required to deploy, maintain and access information and communications services.

Physical parameters impact on the choice of ICT in many ways. For example, the geographical extent of a community, its remoteness, localized population settlement, growth and migration patterns constrain the network architecture, physical topology, scale, scalability and internetworking requirements of appropriate local networks and their wide area counterparts. The topographical profile of the land, the nature of the natural and man-made structures, climactic conditions and natural vulnerabilities as well as the profile of spurious electromagnetic radiation and vulnerabilities to physical intrusion and vandalism are key considerations in the 
choice of transmission media and various other transmission parameters, including transmission frequencies in the case of wireless access.

The maturity of technology standards, the degree to which technologies under consideration comply with international standards, the literature available on the technologies and their uptake locally, regionally and globally are important considerations as they impact on the ultimate ubiquity of communications as well as on the availability and cost of equipment and spares. The existence of legacy communications infrastructure and ancillary services, such as electricity supply and transportation are also important factors in the contemplation of network implementation and ultimately on the price of service to community members. Additionally, the level of regulatory barriers to network deployment and operation are key considerations.

The wherewithal of community members to access ICT through subscription rates, language, literacy, vision, hearing and other means or at various locations are also significant determinants of appropriate technologies.

Table 5 provides an example of the manner in which the technical parameters of technologies may be compared in accordance with the frameworks of Tables 1 and 2 , taking account of the physical context of particular communities as described above. It presents these parameters according to thematic classifications: standards, network architecture, transmission, interface, deployment, application support and 'other'. For simplicity, the table charts an inexhaustive set of access technologies. It does not include the full range of information and communications technologies, as have been briefly discussed in this section.

Table 5 provides a framework, rather than a blueprint, for the categorization of technologies according to technical parameters which derive from the information and communications attributes that are appropriate to particular communities. These attributes are selected on the basis of contextualization in the three domains of the Percolator model, as described in the current and previous sections of this chapter.

In many cases single technologies straddle two or even three reference ranges in the table because it provides course characterizations without regard for the many subtleties of technological capabilities. Implementation of the Percolator model accounts for this fuzziness by recognizing the operational conditions of each technology that may place it in each of the possible reference ranges. For example, in infrastructure mode WiFi networks are implemented with point to point network architectures while in ad hoc mode they are implemented using point to multipoint architectures. Also, their nominal coverage range is $500 \mathrm{ft}$ indoors and $1000 \mathrm{ft}$ outdoors, but they may be specially equipped for extended coverage. As another example, WiFi implementations trade off performance against spectral efficiency, depending on which parameter is more highly valued. Therefore one implementation of a technology may fall into one range in the table while another implementation of the same technology may fall into another. 
Table 5: Sample Mappings of Access Technologies to Reference Technical Parameter Ranges

\begin{tabular}{|c|c|c|c|}
\hline \multirow{2}{*}{$\begin{array}{l}\text { Technical } \\
\text { Parameter }\end{array}$} & \multicolumn{3}{|c|}{ Reference Points } \\
\hline & Low & Mid-range & High \\
\hline \multicolumn{4}{|l|}{ Standards: } \\
\hline Uptake & $\begin{array}{l}\text { One of: local, regional, } \\
\text { global or minimal } \\
\text { installed base } \\
\text { - 3G, FTTH, WiMax, BPL }\end{array}$ & $\begin{array}{l}\text { Two of: local, regional, } \\
\text { global or only modest } \\
\text { installed base } \\
\text { - LMDS/MMDS }\end{array}$ & $\begin{array}{l}\text { Widespread local, regional } \\
\text { and global deployment: } \\
\text { - POTS, WiFi, xDSL, VSAT }\end{array}$ \\
\hline $\begin{array}{l}\text { Compliance and } \\
\text { Maturity }\end{array}$ & $\begin{array}{l}\text { Emerging } \\
\text { - WiMax, BPL }\end{array}$ & $\begin{array}{l}\text { New or maturing } \\
\text {-3G, WLL, WiFi, FTTH }\end{array}$ & $\begin{array}{c}\text { Mature } \\
\bullet \text { POTS, xDSL, VSAT, } \\
\text { LMDS, MMDS,Cellular, CATV }\end{array}$ \\
\hline \multicolumn{4}{|c|}{ Network architecture: } \\
\hline $\begin{array}{l}\text { Scalability of } \\
\text { protocol suite }\end{array}$ & $\begin{array}{c}\text { Protocol suite not } \\
\text { scalable by service } \\
\text { - POTS, XDSL, VSAT, CATV }\end{array}$ & $\begin{array}{l}\text { Protocol moderately } \\
\text { scalable by service } \\
\text { - LMDS, MMDS,WLL, WiFi, } \\
\text { WiMax, FTTH, BPL }\end{array}$ & $\begin{array}{l}\text { Protocol suite highly } \\
\text { scalable by service } \\
\bullet 3 \mathrm{G} \text {, wiMax }\end{array}$ \\
\hline Topology & $\begin{array}{l}\text { Point to point link } \\
\text { - LMDS, WiMAX, VSAT, } \\
\text { leased line }\end{array}$ & $\begin{array}{l}\text { One to many network } \\
\text { • CATV, BPL, WiMax } \\
\text { MMDS,WLL, VSAT, } \\
\text { POTS, XDSL, FTTH }\end{array}$ & $\begin{array}{c}\text { Many to many (i.e. mesh } \\
\text { or partial mesh) network } \\
\text { • WiFi, POTS, XDSL, } \\
\text { FTTH, WLL, LMDS, 3G }\end{array}$ \\
\hline $\begin{array}{l}\text { Physical } \\
\text { architecture }\end{array}$ & $\begin{array}{c}\text { Highly structured architecture } \\
\text { POTS, xDSL, FTTH, } \\
\text { CATV, BPL }\end{array}$ & $\begin{array}{c}\text { Lightly structured architecture } \\
\text {-3G, vSAT, LMDS/MMDS, } \\
\text { WLL, WiMax }\end{array}$ & $\begin{array}{c}\text { Ad hoc architecture } \\
\bullet \text { WiFi }\end{array}$ \\
\hline Reconfigurability & $\begin{array}{l}\text { Difficult to reconfigure } \\
\text { •3G, POTS, XDSL, } \\
\text { FTTH, CATV, BPL }\end{array}$ & $\begin{array}{l}\text { Moderately easy to } \\
\text { reconfigure } \\
\text { - VSAT, LMDS/MMDS }\end{array}$ & $\begin{array}{l}\text { Easily reconfigured } \\
\text { - WiFi, WLL, WiMax }\end{array}$ \\
\hline WAN architecture & $\begin{array}{l}\text { No cost: local network } \\
\text { only, no backhaul } \\
\bullet \text { WiFi }\end{array}$ & $\begin{array}{l}\text { Moderate cost: e.g. } \\
\text { service provider leases } \\
\text { backhaul services } \\
\text { • WLL, WiMax }\end{array}$ & $\begin{array}{l}\text { High cost: e.g. service } \\
\text { provider implements } \\
\text { and maintains backhaul } \\
\text { • LMDS, MMDS, VSAT, } \\
\text { 3G, POTS, XDSL, BPL }\end{array}$ \\
\hline $\begin{array}{l}\text { Local network } \\
\text { architecture }\end{array}$ & $\begin{array}{c}\text { No media to install } \\
\text { - 3G, WiFi, WiMax, VSAT }\end{array}$ & $\begin{array}{c}\text { Hybrid media: some } \\
\text { cabling to install } \\
\text {-WLL, LMDS, MMDS, xDSL }\end{array}$ & $\begin{array}{l}\text { Wired media to install } \\
\text { - POTS, CATV, FTTH, BPL }\end{array}$ \\
\hline Network design & $\begin{array}{c}\text { Minimal technical } \\
\text { expertise required to } \\
\text { design and scale network } \\
\bullet \text { WiFi }\end{array}$ & $\begin{array}{l}\text { Moderate technical } \\
\text { expertise required to } \\
\text { design and scale network } \\
\text { - WiMax, VSAT, WLL }\end{array}$ & $\begin{array}{c}\text { Advanced technical } \\
\text { expertise required to } \\
\text { design and scale network } \\
\text { - 3G, LMDS/MMDS, POTS, } \\
\text { FTTH, CATV, BPL, XDSL }\end{array}$ \\
\hline Internetworking & $\begin{array}{c}\text { Stand alone local network } \\
\bullet \text { WiFi }\end{array}$ & $\begin{array}{l}\text { Local network linked } \\
\text { to specific other } \\
\text { community networks } \\
\bullet \text { WiMax }\end{array}$ & $\begin{array}{l}\text { Local network with } \\
\text { backhaul to the Internet } \\
\text { and / or to PSTN } \\
\text { - POTS, XDSL, 3G, VSAT, WLL, } \\
\text { LMDS/MMDS, FTTH, CATV, BPL }\end{array}$ \\
\hline $\begin{array}{l}\text { Scalability } \\
\text { requirements }\end{array}$ & $\begin{array}{c}\text { No economies of scale } \\
\bullet \text { VSAT }\end{array}$ & $\begin{array}{c}\text { Moderate economies of scale } \\
\text { • POTS, XDSL, WiFi }\end{array}$ & $\begin{array}{c}\text { Significant ecoomies of scale } \\
\qquad 3 \mathrm{G} \text {, WiMax }\end{array}$ \\
\hline Physical security & $\begin{array}{l}\text { Medium and terminal } \\
\text { equipment very } \\
\text { vulnerable to shocks } \\
\text { and intrusion } \\
\text { - POTS, XDSL, BPL }\end{array}$ & $\begin{array}{l}\text { Medium and terminal } \\
\text { equipment moderately } \\
\text { vulnerable to shocks } \\
\text { and intrusion } \\
\text { - 3G, VSAT, WLL, } \\
\text { LMDS/MMDS }\end{array}$ & $\begin{array}{l}\text { Medium robust against } \\
\text { shocks and terminal } \\
\text { equipment minimally } \\
\text { vulnerable to shocks } \\
\text { and intrusion } \\
\text { - FTTH, CATV, WiFi, WiMax }\end{array}$ \\
\hline $\begin{array}{l}\text { Literature } \\
\text { available }\end{array}$ & $\begin{array}{l}\text { Comprehensive technical } \\
\text { and commercialization } \\
\text { information readily available } \\
\bullet 3 G \text {, VSAT, POTS, XDSL }\end{array}$ & $\begin{array}{c}\text { Some technical and } \\
\text { commercialization } \\
\text { information available } \\
\text { - LMDS/MMDS, FTTH, CATV }\end{array}$ & $\begin{array}{l}\text { Comprehensive technical } \\
\text { and commercialization } \\
\text { information not available } \\
\bullet \text { WiFi, WiMax, BPL }\end{array}$ \\
\hline $\begin{array}{l}\text { Cost to install and } \\
\text { operate user } \\
\text { equipment }\end{array}$ & $\begin{array}{l}\text { None } \\
\text { - Only special cases }\end{array}$ & $\begin{array}{l}\text { Moderate } \\
\text { - WiFi, WiMax, 3G, } \\
\text { POTS, xDSL, BPL }\end{array}$ & $\begin{array}{l}\text { High } \\
\text { - VSAT, LMDS/MMDS, } \\
\text { FTTH, CATV }\end{array}$ \\
\hline
\end{tabular}




\begin{tabular}{|c|c|c|c|}
\hline Service cost & $\begin{array}{c}\text { None } \\
\text { - WiFi (some cases) }\end{array}$ & $\begin{array}{c}\text { Moderate } \\
\text { - 3G, POTS, XDSL, BPL }\end{array}$ & $\begin{array}{c}\text { High } \\
\text { - VSAT, LMDS/MMDS, } \\
\text { FTTH, CATV, 3G } \\
\end{array}$ \\
\hline \multicolumn{4}{|l|}{ Transmission: } \\
\hline Bandwidth & $\begin{array}{c}64 \mathrm{kbps} \\
\text { - POTS, VSAT }\end{array}$ & $\begin{array}{l}512 \mathrm{kbps}-10 \mathrm{Mbps} \\
\text { - XDSL, CATV, WiFi, } \\
\text { VSAT, WLL, 3G }\end{array}$ & $\begin{array}{c}\geq 10 \mathrm{Mbps} \\
\bullet \text { BPL, FTTH, WiFi, } \\
\text { WiMax, LMDS/MMDS }\end{array}$ \\
\hline BER & $\begin{array}{c}10^{-3} \\
\text { - } 3 \mathrm{G}, \mathrm{WiFi}\end{array}$ & $\begin{array}{c}10^{-6} \\
\text { - } \text { POTS, }^{\text {XDSL }}\end{array}$ & $\begin{array}{c}\leq 10^{-9} \\
\text { - FTH , CATV }\end{array}$ \\
\hline Timing & $\begin{array}{c}\text { Unbuffered asynchronous } \\
\bullet \text { WiFi }\end{array}$ & $\begin{array}{l}\text { Buffered asynchronous } \\
\text { - POTS, XDSL, BPL, VSAT }\end{array}$ & $\begin{array}{l}\text { Buffered asynchronous } \\
\text { or synchronous } \\
\text { - FTTH, CATV, 3G, POTS }\end{array}$ \\
\hline Encryption & No encryption & $\begin{array}{l}\text { Light encryption } \\
\text { - WiFi, WiMax, BPL }\end{array}$ & $\begin{array}{c}\text { Robust encryption } \\
\text { • VSAT, 3G, FTTH, CATV, XDSL }\end{array}$ \\
\hline Mode & $\begin{array}{l}\text { Simplex } \\
\text { - Traditional CATV, } \\
\text { radio broadcast }\end{array}$ & $\begin{array}{l}\text { Half duplex } \\
\text { - Push to talk radio, } \\
\text { Amateur radio }\end{array}$ & $\begin{array}{c}\text { Full duplex } \\
\text { • 3G, WLL, xDSL, POTS, } \\
\text { BPL, WiFi, WiMax, VSAT, } \\
\text { FTTH,LMDS/MMDS }\end{array}$ \\
\hline Delay & $\begin{array}{c}\text { Days } \\
\text { Mechanical technologies } \\
\text { (e.g. "SneakerNet") }\end{array}$ & $\begin{array}{l}\text { 100's of microseconds } \\
\text { VSAT, XDSL, WiFi, WiMax }\end{array}$ & $\begin{array}{l}\text { Imperceptible } \\
\text { 3G, LMDS/MMDS, } \\
\text { FTTH, CATV, POTS }\end{array}$ \\
\hline $\begin{array}{l}\text { Max geographic } \\
\text { range }\end{array}$ & $\begin{array}{l}300 \mathrm{~m} \\
\cdot \mathrm{WiFi}\end{array}$ & $\begin{array}{c}3 \mathrm{~km} \\
\bullet \text { POTS, LMDS, CATV, FTTH, XDSL }\end{array}$ & $\begin{array}{c}\geq 30 \mathrm{~km} \\
\bullet \text { MMDS, WLL, WiMax, 3G, VSAT }\end{array}$ \\
\hline Media & $\begin{array}{c}\text { Wired } \\
\text { - CATV, FTTH, xDSL, }\end{array}$ & $\begin{array}{l}\text { Wireless MAN } \\
\text { - WiFi, WiMax, MDS/MMDS, } \\
\text { WLL, VSAT }\end{array}$ & $\begin{array}{l}\text { Cellular } \\
\bullet 3 G\end{array}$ \\
\hline $\begin{array}{l}\text { Signal propagation } \\
\text { and penetrability } \\
\text { characteristics }\end{array}$ & $\begin{array}{c}\text { Wired media: robust signal } \\
\text { - CATV, FTTH, xDSL, } \\
\text { POTS, BPL }\end{array}$ & $\begin{array}{c}\text { Low frequency wireless } \\
\text { transmission: moderately } \\
\text { sensitive to environmental } \\
\text { conditions and mediocre } \\
\text { penetrability } \\
\text {-3G, WiFi, WiMax }\end{array}$ & $\begin{array}{l}\text { High frequency wireless } \\
\text { transmission: sensitive to } \\
\text { environmental conditions } \\
\text { and poor penetrability } \\
\text { - LMDS/MMDS, WLL, VSAT }\end{array}$ \\
\hline $\begin{array}{l}\text { Media subject to } \\
\text { regulatory } \\
\text { costs }\end{array}$ & $\begin{array}{l}\text { Transmission disallowed } \\
\text { • Some wireless } \\
\text { frequencies and cable } \\
\text { paths in some jurisdictions }\end{array}$ & $\begin{array}{l}\text { Transmission allowed } \\
\text { with modest barriers } \\
\text { - } 3 \mathrm{G}, \mathrm{CATV}, \mathrm{XDSL}, \mathrm{BPL}\end{array}$ & $\begin{array}{c}\text { Transmission allowed } \\
\text { with few or no barriers } \\
\bullet \text { WiMax, WiFi }\end{array}$ \\
\hline $\begin{array}{l}\text { Media subject to } \\
\text { regulatory costs }\end{array}$ & $\begin{array}{l}\text { No costs for right } \\
\text { of way or licenses } \\
\text { - WiFi (typically) }\end{array}$ & $\begin{array}{l}\text { Low costs of one } \\
\text { or both: right of way } \\
\text { and licenses } \\
\text { - CATV, FTTH, XDSL, POTS, BPL }\end{array}$ & $\begin{array}{c}\text { High costs for right } \\
\text { of way and licenses } \\
\text {-3G, WiMax, LMDS/MMDS, } \\
\text { WLL, VSAT }\end{array}$ \\
\hline \multicolumn{4}{|l|}{ Interface: } \\
\hline $\begin{array}{l}\text { Accessibility to } \\
\text { differently-abled } \\
\text { users }\end{array}$ & $\begin{array}{c}\text { Standard interfaces alone } \\
\bullet \text { xDSL, POTS }\end{array}$ & $\begin{array}{l}\text { Subset of interfaces with } \\
\text { voice activation, touch } \\
\text { screen, audio output } \\
\text { • CATV }\end{array}$ & $\begin{array}{c}\text { Interfaces with voice } \\
\text { activation, touch screen, } \\
\text { audio output } \\
\text { • FTTH, 3G, WiFi, WiMax, } \\
\text { LMDS/MMDS, WLL, VSAT }\end{array}$ \\
\hline $\begin{array}{l}\text { Accessibility to } \\
\text { diverse language } \\
\text { groups }\end{array}$ & $\begin{array}{l}\text { Interface presented } \\
\text { in single language }\end{array}$ & $\begin{array}{l}\text { Interface presented } \\
\text { in more than one } \\
\text { international language }\end{array}$ & $\begin{array}{l}\text { Interface presented in } \\
\text { international language } \\
\text { as well as dialects }\end{array}$ \\
\hline Familiarity & $\begin{array}{c}\text { Unfamiliar end user } \\
\text { appliance and operation } \\
\text { - WiFi, WiMax, LMDS/MMDS, } \\
\text { VSAT, FTTH }\end{array}$ & $\begin{array}{c}\text { Familiar end user } \\
\text { appliance but new operation } \\
\text { or vice versa } \\
\text { - xDSL, BPL, CATV, WLL }\end{array}$ & $\begin{array}{c}\text { Familiar end user } \\
\text { appliance and operation } \\
\bullet \text { POTS, 3G }\end{array}$ \\
\hline Usability & $\begin{array}{l}\text { Complicated installation, } \\
\text { configuration \& operation } \\
\text { - LMDS/MMDS, VSAT, FTTH }\end{array}$ & $\begin{array}{l}\text { Some installation and } \\
\text { configuration required of user. } \\
\text { Operation somewhat simple } \\
\text { - WiFi, WiMax, XDSL, } \\
\text { BPL, CATV, WLL }\end{array}$ & $\begin{array}{c}\text { No installation or } \\
\text { configuration required } \\
\text { of user. Operation simple } \\
\text { • POTS, 3G }\end{array}$ \\
\hline \multicolumn{4}{|l|}{ Deployment: } \\
\hline Time to deploy & $\begin{array}{l}\text { Days } \\
\text { - vSAT, WiFi, }\end{array}$ & $\begin{array}{c}\text { Months } \\
\text { - WiMax, XDSL, 3G }\end{array}$ & $\begin{array}{c}\text { Years } \\
\text { - CATV, LMDS/MMDS, FTTH }\end{array}$ \\
\hline
\end{tabular}


In the Technology domain the relative weightings attached to physical resources, including available spectrum and maximum transmit power restrictions, are taken into account in the selection of base technologies and their particular implementations.

\subsection{ICT SOLUTIONS}

The ultimate ICT solutions that are selected at the top of the Percolator model enable end user applications which are in turn enabled by information and communications services, whose technical requirements are well documented.

As is the case for the Base Domain, the Technology Domain forms the basis of many solution "trees". In particular, each unique application environment can be associated with its own solution set comprising unique solution branches. The solution branches in turn comprise various combinations of technologies, appropriately adapted to the environment to provide individual solutions. It is these solutions, and not information and communication technologies of themselves, that represent tangible avenues for developmental impact. They variously surround applications relating to commerce, health, education, civic participation, news, cultural and artistic expression, entertainment, enterprise and a rich array of livelihoods.

For each solution tree, the Percolator model is implemented by using a custom weighting system attached to context parameters in each domain. For example, in the Technology domain, a community that lies at the heart of a hurricane belt will attach a particularly high weighting to natural disasters and consequently value physical security very highly. In communities whose buildings are constructed according to rigorous building codes, path obstruction is a particular concern and consequently wired technology solutions may be favored over their less robust wireless counterparts.

For poor communities, key parameters in the determination of ultimate ICT solutions often relate to the simplicity with which network infrastructure can be assembled and operated; the degree to which the network may grow and shrink in an ad hoc manner, the flexibility and accessibility of communications appliances and the energy requirements of network and user equipment. For such communities, the flexibility of multihop or mesh network architectures in ad hoc wireless networks (Corson \& Macker, 1999) and the innovative use of supportive technologies including alternative energy technologies and open source software (Proenza, 2005) hold great potential, though there is much debate as to the total cost of ownership for the latter (UNCTAD, 2003; Dravis, 2004).

Quite apart from the choice of information and communications technologies, the success of ICT solutions for digitally poor communities is very closely linked to 
models of ownership as well as to service and access models. Galperin and Girard's chapter explore these dimensions.

Information and communications solutions span the range of technologies which are purely physical, such as Sneakernet, to the intermediate DakNet (Jhunjhunwal \& Orne, 2003), to the purely digital. Financial, cultural and social constraints of low resource communities may well dictate a valid choice of nontechnical or low-technical solutions notwithstanding the fact that this chapter has only considered purely digital solutions.

\section{Conclusion}

In the Percolator model, the ultimate application for which ICTs are used is tied closely to developmental objectives. The model offers a framework in which solutions may be contemplated in a systematic and manageable way, taking account of ultimate developmental objectives as well as various contextual parameters and the technical features of available information and communications technologies.

As with all frameworks, application of the Percolator model requires customization. In particular, the unique nature of various communities must be coded in a weighting scheme that applies to the many context parameters that have been partitioned according to three fundamental domains: Base, User and Technology. Ultimate ICT solutions, built on basic technologies, are tremendously influenced by innovative spins that derive from sensitivity to physical, social and politico-cultural contexts, a sensitivity that is refined through the systematic process of percolation. Solutions range from generic use of standard technologies and application philosophies to the use of many technologies in hybrid solutions.

This chapter has focused on ICT solution trees in the Percolator model. Nevertheless, the model is far more general and may be applied to a number of other technologies. For example, a Base domain which favors livelihoods that incorporate some element of trade, as an economic agent and based on strong cultural traditions, may form the basis of a solution tree constructed for mechanical technologies. In the User domain, such a tree incorporates the attributes ascribed to transport for example: speed, waiting time, number of passengers, space for goods, seating arrangement, cleanliness, regularity. The attributes, filtered by the social context, determine the technical requirements of transportation technologies appropriate to community members. These requirements constitute the technical requirements basket and are specified as far as possible in quantitative terms, for example "a minimum speed of 2 miles per hour" or "a minimum capacity of two human beings and 5 cubic feet of storage space". The technical requirements basket forms the basis of the choice of transportational technologies among those that are possible for the 
community (for example donkey cart, private car and public bus) and motivate particular choices (for example donkey cart) of transport to best serve the purposes of particular community members. The Percolator model may therefore be applied to intervention based on a variety of different technological disciplines.

The model provides an incremental approach to solution deployment and implementation, particularly well suited to communities of severely limited resources. It describes an iterative process of solution finding that tracks the dynamism of developmental targets and available technologies.

At the heart of the Percolator model is the separation of the attributes of information and communications from the technologies used to deliver information and communications services. This, along with the model's deep emphasis on the many dimensions of contextualization, is important in ensuring that ICT are introduced in a manner that is acceptable and accessible to community members. This, in turn, is vital to the gradual but effective adoption of ICT by communities that are under serious threat of digital exclusion. 


\section{References}

Alvén, D., Arjunanpillai, R., Farhang, R., Kansal, S., Khan, N, \& Leufven, U. (2001). Hotspots Connect the Dots for a Wireless Future. Final report on Analysis of a $3 G$ alternative for Ericsson Business Innovation and Telia Research. Retrieved from http://www.dsv.su.se/ mab/Alven.pdf.

Ashley, C. \& Carney, D. (1999). Sustainable Livelihoods: Lessons from early experience. London: DFID.

Avgerou, C. (2000). Recognizing Alternative Rationalities in the Deployment of Information Systems. The Electronic Journal on Information Systems in Developing Countries, 3(7), 1-15.

Cecchini S. \& Shah T. (2002). Information and Communications Technology as a Tool for Empowerment. World Bank Empowerment Sourcebook: Tools and Practices 1. Washington, DC: The World Bank.

Corson, S \& Macker, J. (1999). Mobile Ad-hoc Networking (MANET). IETF RFC 2501, January. Retrieved from http://www.faqs.org/rfcs/rfc2501.html

Davis, F.D. (1993). User Acceptance of Information Technology: System characteristics, user perceptions and behavioral impacts. International Journal of Man-Machine Studies, Vol. 38, pp. 47587.

DFID. (2002). The Significance of Information and Communication Technologies for Reducing Poverty. London: DFID. Retrieved September, 2005, from http://www.dfid.gov.uk/pubs/files/ictpoverty.pdf

Dravis, P. (2003). Open Source Software: Perspectives for Development. World Bank (InfoDev). Retrieved July, 2005, from http://wbln0018.worldbank.org/ict/resources.nsf/D045B0DD4551DA0885256B29005FCE67/87 9F7A7745A5053D85256E750063416D?OpenDocument.

Ferro, E. \& Potorti, F. (2005). Bluetooth and Wi-Fi Wireless Protocols: A survey and comparison. IEEE Wireless Communications. Retrieved from http://dienst.isti.cnr.it/Dienst/Repository/2.0/Body/ercim.cnr.isti/2004-TR27/pdf?tiposearch $=$ cnr\&langver=

G-8. (2000). Okinawa Charter on the Global Information Society. G8 Information Centre. Toronto: University of Toronto.

Jhunjhunwala, N. \& Orne, P. (2003). The Wireless Internet Opportunity for Developing Countries. The Wireless Internet Institute (Ed.). Washington, D.C.: World Times, Inc. InfoDev.

Lehr, W. \& McKnight, L. (2003). Wireless Internet access: 3G vs. WiFi? Telecommunications Policy, 27, $351-370$.

Otero, J. (2004). WiFi and WiMax. Caribbean Telecoms Briefing, Part 1. London: Informa Telecoms Group.

Proenza, F. (2005). Strategic Open Source Software: Choice for Developing Country Governments. i4d magazine June 2005. Retrieved September, 2005, from http://www.i4donline.net/june05/opensource.asp

Riti, M. D. (2001). Simputer: The Computer for the Masses. Rediff Business. Retrieved September, 2005, from http://www.rediff.com/money/2001/apr/24spec.htm

Tse, T., Tiong, J. \& Kangaslahti, V. (2004). The Effect of Cultural Norms on the Uptake of Information and Communication Technologies in Europe: A Conceptual Analysis. International Journal of Management, 21(3) 382-392.

UNCTAD. (2003). E-Commerce and Development Report. UNCTAD/SDTE/ECB/2003/1. Retrieved July, 2005, from http://r0.unctad.org/ecommerce/ecommerce_en/edr03_en.htm

UNDP. (1996). Human Development Report 1996. New York: Oxford University Press. 1996. Retrieved June, 2005, from http://hdr.undp.org/reports/global/1996/en/ 
UNDP. (1999). New Technologies and the Global Race for Knowledge in Making New Technologies Work for Human Development. In UNDP Human Development Report 1999. New York: UNDP.

Vaughan, D. (2005). ICT4D: An Integrated Approach for Village Communities. Gladesville: Partners in Micro-Development.

Wanmali, S. (1998). Participatory Assessment and Planning for Sustainable Livelihoods. Retrieved August, from http://www.undp.org/sl/Documents/Strategy_papers/Participatory_Assessment_for_SLSW.ht m/PAPSL.htm.

Wattegama, C. (2004). Bridging the 'Analogue' and Digital Divides: The Unique Experience of Sri Lanka. Second i4d Seminar, 27 - 28 August 2004. China. Retrieved September, 2005, from http://www.i4donline.net/events/2ndi4d/chanukal.htm.

World Bank. (1999). Knowledge for Development, World Development Report 1998/99. Washington DC: World Bank. Retrieved September 20, 2005, from http://info.worldbank.org/ict/assets/docs/ExecSum.pdf 